Article

\title{
Will ICMT Access and Use Support URM Students' Online Learning in the (Post) COVID-19 Era?
}

\author{
Sunha Kim ${ }^{1, *}$, Suzanne Rosenblith ${ }^{2}$, Yunjeong Chang ${ }^{3}\left(\mathbb{D}\right.$ and Shira Pollack ${ }^{4}$ (i) \\ 1 Department of Counseling, School, and Educational Psychology, and Learning and Instruction, \\ Graduate School of Education, University at Buffalo, the State University of New York, \\ Buffalo, NY 14260, USA \\ 2 Graduate School of Education, University at Buffalo, the State University of New York, Buffalo, NY 14260, USA; \\ rosenbli@buffalo.edu \\ 3 Department of Learning and Instruction, Graduate School of Education, University at Buffalo, the State \\ University of New York, Buffalo, NY 14260, USA; ychang28@buffalo.edu \\ 4 Department of Counseling, School, and Educational Psychology, Graduate School of Education, University \\ at Buffalo, the State University of New York, Buffalo, NY 14260, USA; shirapol@buffalo.edu \\ * Correspondence: sunhakim@buffalo.edu
}

Received: 23 August 2020; Accepted: 28 September 2020; Published: 13 October 2020

check for updates

\begin{abstract}
In view of the United Nations' (UN's) Sustainable Development Goal (SDG) for education (SDG4), this study explored how information and communications and media technology (ICMT) access and uses for learning have influenced students' perceived success during the COVID-19 pandemic era and the differential effects of ICMT access and use on underrepresented minority (URM) and non-URM students. This study applied structural equation modeling (SEM) analysis using data from students who experienced online transition in one large public university in the United States. The results showed that ICMT uses for learning benefitted URM students but lack of ICMT access had a negative effect on online learning among URM students. We discussed the implications of these findings in the context of online education, digital inclusion, and the UN's SDG4.
\end{abstract}

Keywords: ICMT access; ICMT use; UN sustainable development goal; COVID-19 era; underrepresented minority students

\section{Introduction}

The COVID-19 pandemic, which started in late 2019 and has swept across the world since early 2020, led schools in the United States and internationally to shut down. As a result, more than 290 million students globally have been affected by school closures, and schools must rapidly transform offline learning activities into online learning [1,2]. Regarding rapid and forced online transition, there have been ongoing debates on whether online education could sufficiently replace offline education, whether students' residence is an advantageous learning milieu, whether online education reinforces extant inequalities, and whether online education helps achieve the United Nations' (UN's) Sustainable Development Goal (SDG) for education, which promotes the provision of quality education for all [3-5]. In the midst of these debates, this study responds to the call for research on online education to shed light on effective approaches to and potential issues with promoting online educational success for all students during and beyond the COVID-19 era. Specifically, this study analyzed the role of information and communications and media technology (ICMT) access and ICMT learning uses in students' online learning, with attention focused on minority students.

Researchers have revealed an important association of ICMT access with students' academic success [6-8], but considering the exponential increase in ICMT access in recent years, scholars have 
raised a call for research on digital divides beyond physical access to ICMT [9-11]. However, a recent study showed the importance of the physical ICMT access divide between minority and non-minority students, which has led to negative effects on student success [12]. Moreover, there has been grave concern over the physical ICMT access among minority students, considering the limited ICMT access at other public places including schools during the COVID-19 pandemic lockdown, which could widen existing educational inequalities and become threats to the sustainable development of minority students [13].

As ICMT has penetrated deeply the daily lives of students who have revealed a special attachment to it, there have been many attempts to integrate ICMT use into education [14-16]. Despite increasing interest in ICMT uses, there have been mixed results on ICMT uses for education [17-19]. To make things worse, ICMT uses for education did not seem equally inclusive of all students, reporting differential ICMT uses for learning between minority and non-minority students [20,21]. Consequently, differential effects of ICMT use on these two groups of students were detected, but no consensus has been reached on whether ICMT uses serve to mitigate or exacerbate existing educational gaps [22-24]. Considering the increasing need for effective strategies to integrate ICMT into online education and promote digital inclusion for all students $[15,25]$, this study sought to investigate the effect of ICMT uses for the learning of underrepresented minority (URM) students. Furthermore, considering the potentially differential impact that COVID-19 can have on girls and boys, women and men [26], this study explored the potential differences in ICMT access and use on male and female students. Our empirical findings are expected to shed insights on mixed results on gender differences in learning gains in online learning environments $[27,28]$.

To conduct an empirical investigation on ICMT access and uses for learning, we employed data from students in one university in the United States who experienced an online transition during the 2020 spring semester. Using Mplus 8.4, we applied a structural equation modeling (SEM) analytic method, which is suitable to explore the direct effects of ICMT access and uses as well as potential differences in these direct effects between different groups of students $[29,30]$. The following research questions guided this study:

- Will ICMT access and use for learning enhance or constrain URM students' perceived success in online instruction?

- Will there be differential effects of ICMT access and uses on perceived online success between female and male students?

Our specific hypotheses for this study are as follows:

- Hypothesis 1: Lack of ICMT access will constrain students' perceived success in online instruction [6-8].

- Hypothesis 2: ICMT use for learning will enhance students' perceived success in online instruction [12,22,31,32].

- Hypothesis 3: There will be a differential effect of ICMT access between female and male students [26,33].

- Hypothesis 4: There will be a differential effect of ICMT uses between female and male students [28,34].

\section{Literature Review}

\subsection{Learning Benefits of Information and Communications and Media Technologies (ICMTs)}

The use of learning technologies enables contemporary students to learn how to operate and function in today's society. To illustrate, information and communications and media technologies (ICMTs) have the potential to enhance deeper learning that requires 21st-century learners. Deeper learning involves understanding complex concepts and complex problem solving, reasoning, inferential thinking, and transfer of knowledge to new situations [35]. ICMTs enable deeper learning by providing multiple learning choices and opportunities for users; ICMTs provide learners with opportunities to interact and communicate with other people with technologies, choices to adapt the use of the technologies per individual interest, and linked representations via various modes (e.g., spoken, 
messages, texts, diagrams, videos, or simulations) [36]. The use of technology also enhances deeper conceptual learning via technology-enhanced communication and collaboration rather than receiving lecture-driven or direct instruction [37]. Collaborative tools (e.g., Wiki, Google Docs), communication tools (e.g., Google Hangouts, WhatsApp), and social media (e.g., Facebook, Twitter, and Instagram), for example, allow learners to collaboratively acquire new knowledge and thinking skills.

Furthermore, ICMTs assist students in their learning by presenting information in a way that enhances their learning and motivation by adapting various instructional strategies. For example, to sustain learner motivation, game-based learning has been adapted to engage learners for academic purposes by using technologies such as digital games, social media, and online affinity groups [38,39]. ICMT-enhanced and online learning environments also provide more opportunities for learners to reflect on the learning process than that might occur during face-to-face classroom settings without technology. In one study, 22 student participants were interviewed regarding their asynchronous learning experiences. Participants expressed that the asynchronous learning environment allowed them to think and write more carefully about their ideas [40]. Learners reported that they were more careful and thoughtful before posting in online discussions for their classmates and teachers to read over than they were in in-person classroom settings. Yet, various learning benefits of ICMTs remain inconclusive when it comes to individually different learners who have different access, prior experiences, and preferences in using technologies.

\subsection{Various Factors Affecting Online Learning with ICMT}

While the benefits of integrating ICMTs into education have been acknowledged, research has also examined various factors affecting individual students' learning in ICMT-enhanced learning environments. Individually different prior experiences and affordances levels in using ICMT have been indicated as possible factors that variate the effectiveness of ICMT-based learning. A study assessing ICMT literacy among a large sample of college students found strong correlations between the frequency of ICMTs use, confidence in their ICMT skills, and overall academic performance [41]. Similarly, anxiety on using technologies due to a lack of experience in using technology for learning affects online learning experiences [42]. Students appeared to experience a form of "learning displacement", where they were unsure of what was expected of them. The newness of the ICMT-enhanced learning environment and format contributed to this spike in anxiety amongst learners. However, once they became familiar and understood the simplicity of the online format, their anxiety dissipated. Another study reported negative views towards using the Internet for schools, suggesting a need for improving student attitudes toward ICMTs as a learning tool [43].

Less experience in ICMT-based or online learning also yields diverse levels of self-regulated online learning strategies which will ultimately affect online learning experiences. A study surveyed students to assess their perceptions of online learning and found that some students have difficulties coping with the workload while others do not [44]. Frustrated students failed to align to match the level of work for an assessment task and the amount of effort required for the task. Furthermore, an asynchronicity feature of online learning hampered students' positive learning experiences with technologies. Students were frustrated when receiving delayed feedback rather than immediate feedback from peer learners or from the instructor [40]. It is evident that the design of the course, confidence levels on utilizing learning technologies, and time management skills of an individual student affect an individual learner's successful online learning experiences [45]. Thus, examining on how ICMT may diversely benefit or affect the learning of students from individually different backgrounds will be meaningful to broaden the positive impact of ICMTs in education.

\subsection{ICMTs Access and Underrepresented Minority Students (URM)}

An individual student in higher education has had different access to ICMTs due to multiple reasons such as lack of technical infrastructure, lack of affordability, or lack of digital literacy [46]. Cultural (e.g., race, ethnicity) or socioeconomic (e.g., parental income, education, and occupation) 
backgrounds of each student may affect ICMT access. Given the fact that only $58 \%$ of the world's population has access to the Internet [47], students from some particular countries in the world or in some regions in a country may have fewer learning experiences in ICMT-enhanced or online learning environments. Certain cultures may have different perceptions regarding technology use which influences their initial acceptance of these technologies [48]. Due to its relatively novel presence in society, ICMTs may not be well received in developing countries where integrating learning technologies are not a part of their culture [49]. Scholars addressed their concerns on the digital divide as different access to ICMT could aggravate existing education inequalities. Unequal access to technologies, both at school and at home, can increase educational and social stratification, creating a new digital divide [50].

Researchers have raised concerns that URM (e.g., Black African, Latino, and Native American) students are less likely to have a computer and internet access in their homes than white students. Less accessibility may yield fewer technological experiences which will consequently influence an individual student's different learning preferences [51]. While concerns caused by the digital divide have been raised, only a few studies with small sample sizes raised possible disparities between URM and non-URM students' learning. Brown, Wohn, and Ellison [52] found from an interview study that low-income prospective college students (i.e., high school students) had more difficulties in interpreting and applying the knowledge found from the Internet than those from high-income status. $\mathrm{Du}, \mathrm{Ge}$, and $\mathrm{Xu}$ [53] found from an interview study that African-American female students had a timid attitude toward online discussions while they preferred to become a leader during the in-person group work. For Hispanic/Latino students, Smith and Ayers [54] conducted an interview study and found Latino students received less benefit from online learning than Caucasian students. However, previous studies were conducted with a small sample size of students and without statistical measurement. An empirical study with statistical measurement with a larger sample size is necessary to generalize the findings in order to examine how unequal access to ICMTs affects historically underrepresented minority students' learning.

\section{Materials and Methods}

This study analyzed the data from students who experienced an online transition in one university in western New York during the 2020 spring semester. Particularly, we paid attention to URM students ( $n=240 ; 14.1 \%$ of the total students of 1699). Non-URM students include white and Asian students and URM students include other ethnicities/races (e.g., Afro-American, Latino, and Native American). The data were collected using a survey instrument to measure student learning and instructional effectiveness during the COVID-19 emergency. The survey was developed by a group of experts in the office of Educational Effectiveness based on the pressing needs expressed by the senior leadership team of the university and examples shared on a national assessment listserv. This study was Institutional Review Boards (IRB)-exempt. The data dashboards based on survey results are available at http://www.buffalo.edu/oee/outreach-and-education/remoteinstruction2020.html.

The predictors of interests are students' perceived adequacy of ICMT access (access) and perceived effectiveness of ICMT uses (ICMT). Access is represented by students' perceived adequacy of their computer and other devices (computer) and of their internet connection (internet) for completing their coursework online, coded 0 for adequate and 1 for inadequate. ICMT asks students' perceived effectiveness of using ICMT for online instruction such as Blackboard-Discussion Boards (ICMT1), Blackboard-Groups (ICMT2), and email (ICMT3), ranging from 1 (not at all effective) to 4 (extremely effective). Outcome variables of interest are students' perceived online success (online), comprising of two variables, which asks students about their beliefs in their successful learning of the course content (succeed) and their comfort level of completing their coursework online (complete), with responses ranging from 1 (strongly disagree) to 5 (strongly agree).

The rate of missingness was detected among only ICMT-related variables, ranging from $6.7 \%$ (ICMT2 and ICMT3) to 7.1\% (ICMT1). A missing completely at random (MCAR) test revealed that the 
data were MCAR (missing completely at random), with chi-square $=20.507, d f=29, p=0.387$ [55]. To address missing data, this study adopted a full information maximum likelihood (FIML) method to treat missing data given its capability to set forth less biased results compared with other methods including simple imputation [56-58]. In addition, this study utilized the robust estimator, considering its robustness to the potential violation of assumptions such as data non-normality $[30,59,60]$.

Using Mplus 8.4 [29] as the main statistical models, this study adopted structural equation modeling (SEM), to analyze the direct effect of ICMTs on students' success, and the effect of ICMTs on students' success moderated by students' gender. To assess overall model fits, this study adopted multiple fit indices [29,61]: insignificant chi-square $\left(X^{2}\right)$ results or significant results when accompanied by other acceptable fit statistics for sample sizes of over 200; the root-mean square error of approximation (RMSEA) and the standardized root-mean square residual (SRMR) with values of less than 0.08; the Tucker-Lewis index (TLI); and the comparative fit index (CFI) with values greater than 0.95.

Figure 1 depicts the conceptual model with ICMT access (access) from two indicators (computer and internet); ICMT use constructs (ICMT) from three ICMT use indictors (ICMT1, ICMT2, and ICMT3); and the outcome variable, online, resulted from two indicators (succeed and complete). To investigate the internal consistency among indicator variables for the latent constructs, this study performed reliability tests and obtained omega coefficients $(\omega)$ [62] as composite reliability measures [63,64]. The reliabilities of online, access, and ICMT are $\omega=0.874$ (S.E. $=0.024, p<0.001), \omega=0.707$ (S.E. $=0.087$, $p<0.001$ ), and $\omega=0.743$, (S.E. $=0.032, p<0.001)$, respectively. These results were aligned with those from the confirmatory factor analysis (CFA) that we adopted at the first stage, prior to a full SEM model, following a two-step approach $[61,65]$. The CFA model revealed acceptable fit statistics $\left(X^{2}=490.469\right.$, $p<0.01$; RMSEA $=0.057$; CFI $=0.982$; TLI $=0.965$; SRMR $=0.027)$. The indicator variables held significant loading on their respective latent constructs as follows: computer (0.571) and internet (0.578) for access; ICMT1 (0.798), ICMT2 (0.890), and ICMT3 (0.543) for ICMT; and succeed (0.853) and complete $(0.819)$ for online. Then, at the second stage, by adding paths among latent constructs, we built a full SEM model to investigate the direct effects of ICMT variables on student success to test our hypotheses 1 and 2. The direct path from access to online tests the hypothesis 1: lack of access will have a negative effect on URM students' perceived online success. The direct path from ICMT to online tests the hypothesis 2: effective ICMT use will have a positive effect on online success.

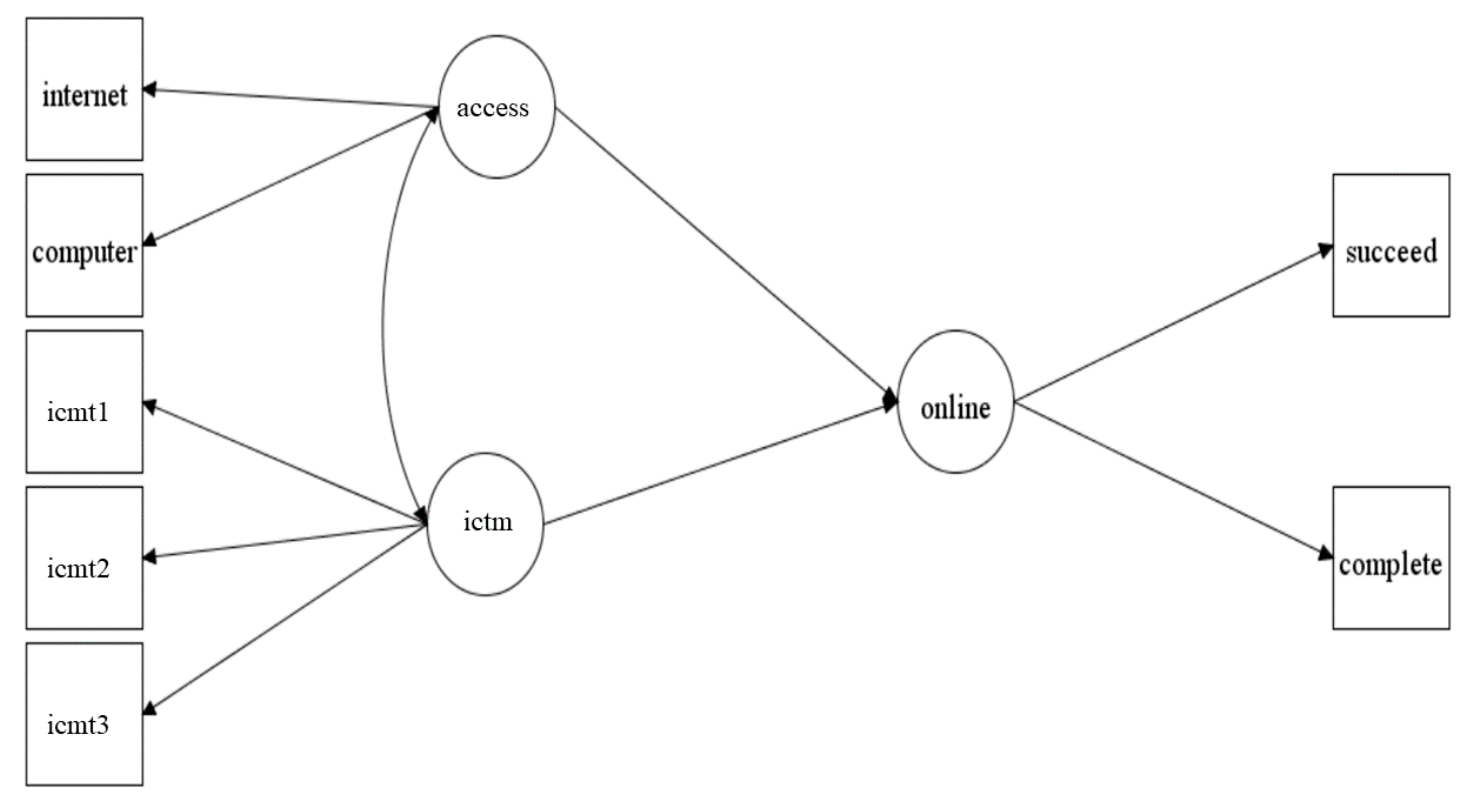

Figure 1. Conceptual diagram of a full structural equation modeling (SEM) model.

To test hypotheses on the potential differences in the direct effects between two gender groups, we adopted a latent moderated structural equation (LMS) method [66], which builds a series of SEM 
models using two-step estimation procedures. In the first step, we built the baseline LMS model without the latent interaction term. In the second step, we constructed the final LMS model, by including the latent interaction term (genxacc and genxicmt). A log-likelihood ratio test was conducted to investigate the relative fit of the final and baseline LMS models. The test statistic for a log-likelihood ratio $(D)$ was calculated using the following equation, and the $D$ statistic was compared to a $\mathrm{X}^{2}$ distribution [67]:

$$
D=-2 \text { [(log-likelihood for baseline LMS model })-(\log -\text { likelihood for final LMS model })]
$$

Furthermore, to aid the interpretation of a significant latent interaction effect, we built the loop plot of the latent variable interaction [29]. Specifically, to test hypotheses 3 and 4, we built two LMS models as follows: the LMS access model tested hypothesis 3 on the potential differential effect of access between male and female URM students by adding genxacc (See Figure 2), and the LMS ICMT model investigated hypothesis 4 on the differential effect of ICMT by including genxicmt (See Figure 3).

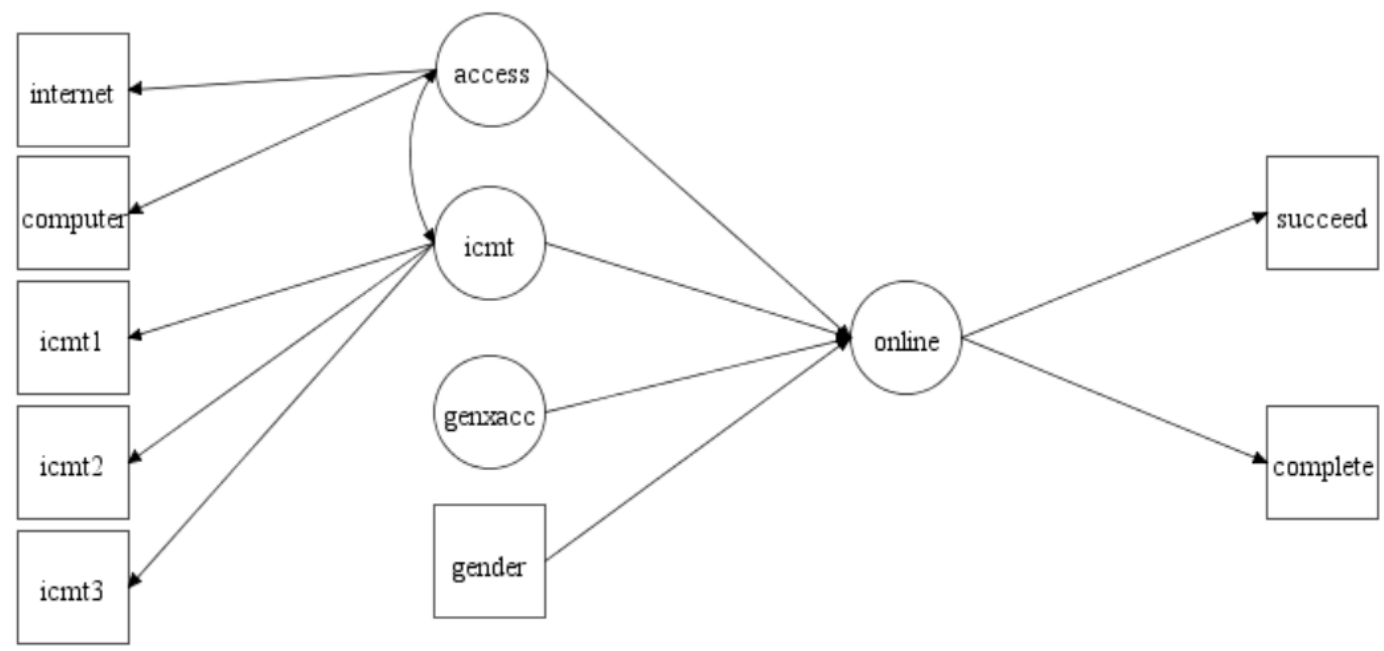

Figure 2. Conceptual diagram of a latent moderated structural equation (LMS) access model.

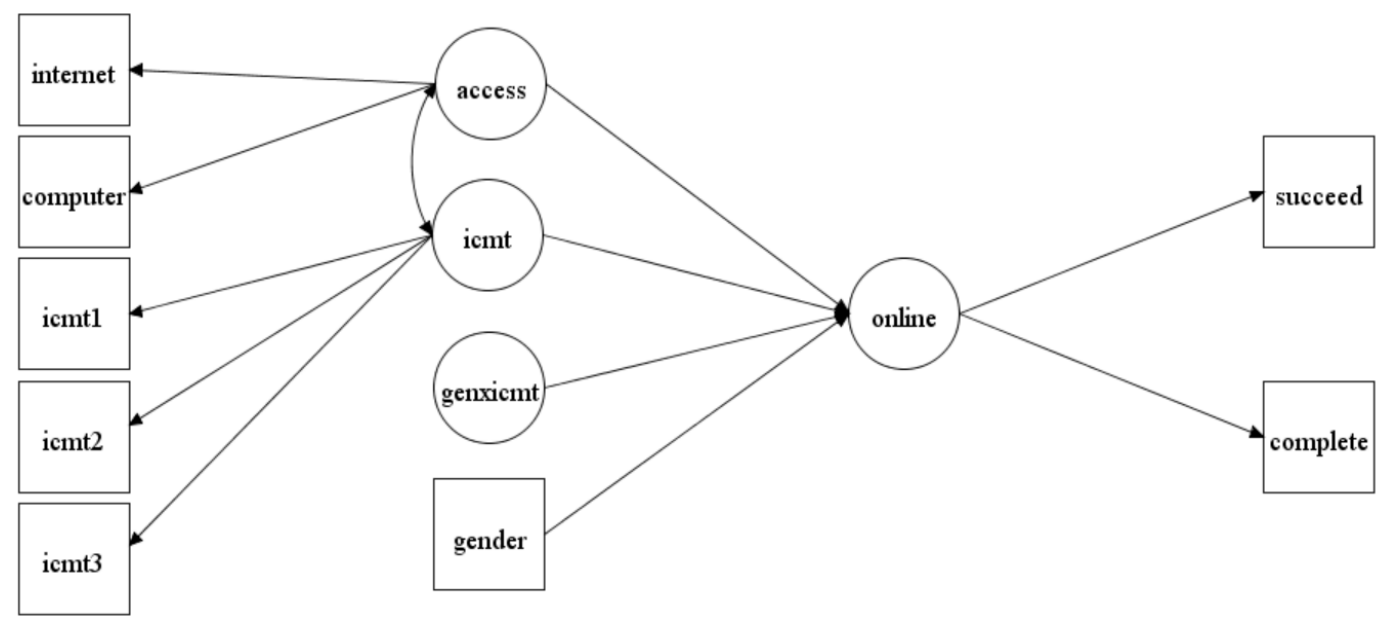

Figure 3. Conceptual diagram of an LMS information and communications and media technology (ICMT) model.

\section{Results}

Table 1 shows the descriptive statistics and correlation analyses results of study variables. 
Table 1. Descriptive statistics and correlations.

\begin{tabular}{|c|c|c|c|c|c|c|c|c|c|}
\hline \multicolumn{2}{|c|}{$\begin{array}{l}\text { Observed } \\
\text { Variables }\end{array}$} & \multirow{2}{*}{$\begin{array}{l}1 . \\
-\end{array}$} & \multirow[t]{2}{*}{2.} & \multirow[t]{2}{*}{3.} & \multirow[t]{2}{*}{4.} & \multirow[t]{2}{*}{5.} & \multirow[t]{2}{*}{6.} & \multirow[t]{2}{*}{7.} & \multirow[t]{2}{*}{8.} \\
\hline 1. & Complete & & & & & & & & \\
\hline 2. & Succeed & $-0.698^{* *}$ & - & & & & & & \\
\hline 3. & Computer & $-0.272^{* *}$ & $-0.273^{* *}$ & - & & & & & \\
\hline 4. & Internet & $-0.243^{* *}$ & $-0.260^{* *}$ & $0.330 * *$ & - & & & & \\
\hline 5. & ICMT1 & $0.461^{* *}$ & $0.529^{* *}$ & -0.095 & $-0.175^{* *}$ & - & & & \\
\hline 6. & ICMT2 & $0.538^{* *}$ & $0.528^{* *}$ & $-0.215^{* *}$ & $-0.287^{* *}$ & $0.728 * *$ & - & & \\
\hline 7. & ICMT3 & $0.329 * *$ & $0.422 * *$ & -0.133 * & $-0.161 *$ & $0.410^{* *}$ & $-0.504^{* *}$ & - & \\
\hline \multirow[t]{5}{*}{8.} & Gender & $0.171^{* *}$ & 0.132 * & -0.057 & 0.066 & $0.166^{*}$ & $0.214^{* *}$ & 0.115 & - \\
\hline & Mean & 2.054 & 2.863 & 0.1833 & 0.2458 & 2.709 & 2.821 & 3.005 & 0.604 \\
\hline & $S D$ & 1.007 & 1.225 & 0.388 & 0.431 & 1.014 & 9.72 & 0.982 & 0.490 \\
\hline & Skewness & 0.436 & 0.086 & 1.647 & 1.188 & -0.332 & -0.402 & -0.611 & -0.429 \\
\hline & Kurtosis & -1.035 & -0.988 & 0.719 & -0.594 & -0.969 & -0.820 & -0.715 & -1.832 \\
\hline \multicolumn{2}{|c|}{$\begin{array}{c}\text { Latent } \\
\text { Variables }\end{array}$} & \multicolumn{3}{|c|}{1.} & \multicolumn{2}{|c|}{2.} & \multicolumn{3}{|c|}{3.} \\
\hline 1. & Online & - & & & & & & & \\
\hline 2. & Access & $-0.545^{* *}$ & - & & & & & & \\
\hline 3. & ICMT & $0.719^{* *}$ & $-0.418^{* *}$ & - & & & & & \\
\hline
\end{tabular}

As shown in Table 2, our full SEM model revealed acceptable fit statistics: $X^{2}=490.469, p<0.01$; RMSEA $=0.057<0.08 ;$ CFI $=0.982>0.95 ;$ TLI $=0.965>0.95 ;$ SRMR $=0.027<0.08$. About $59 \%$ of variance of online was explained in this model (R-Square $=590$, S.E. $=0.069, p<0.01)$.

Table 2. Model fit statistics.

\begin{tabular}{ccccccc}
\hline Fit Statistics & Chi-Square & RMSEA & CFI & TLI & SRMR & R-Square \\
\hline Estimate & $490.469, p<0.01$ & 0.057 & 0.982 & 0.965 & 0.027 & $0.590, p<0.01$ \\
\hline
\end{tabular}

As presented in Figure 4, access had a significant negative direct effect on students' online success $(\beta=-0.297$, S.E. $=0.083, p=0.000)$. Thus, among URM students, limited ICMT access was associated with lower online success. However, there was a significant positive direct effect of ICMT use on online success $(\beta=0.595$, S.E. $=0.070, p=0.000)$. A higher level of perceived effectiveness of ICMT use for online learning was related to higher online success. Thus, our hypotheses 1 and 2 on access and ICMT were supported. 


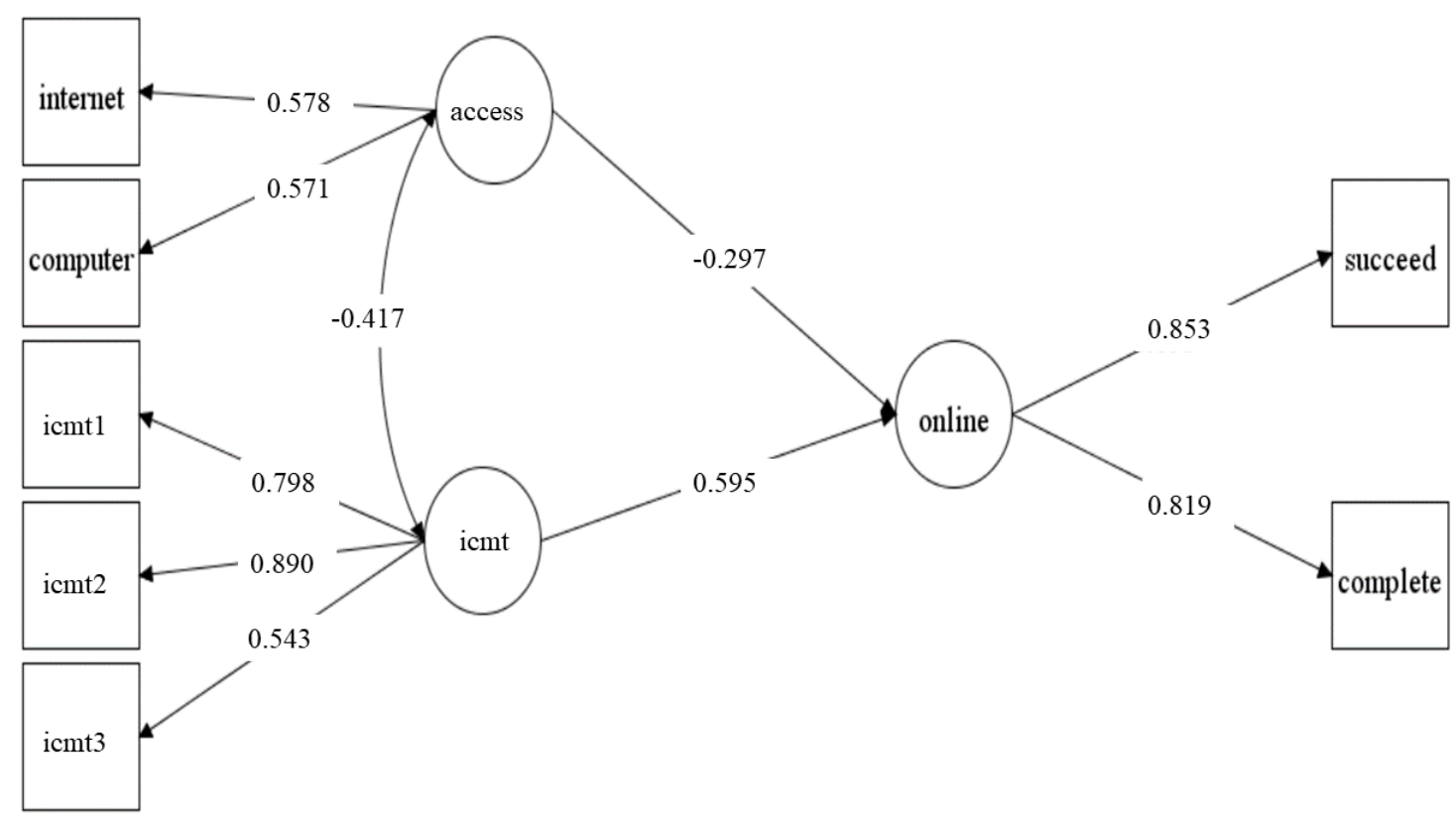

Figure 4. Conceptual diagram of a full SEM model with parameter estimates.

The relative fit of the final LMS versus baseline access model was investigated via a log-likelihood ratio test, resulting in a log-likelihood difference value of $D=1.734(p>0.05)$. The LMS access model revealed no gender difference with no significant interaction term of gender*access (genxacc) with $\beta=-0.094$, S.E. $=0.059, p>0.05$ as presented in Figure 5. Thus, hypothesis 3 was not supported.

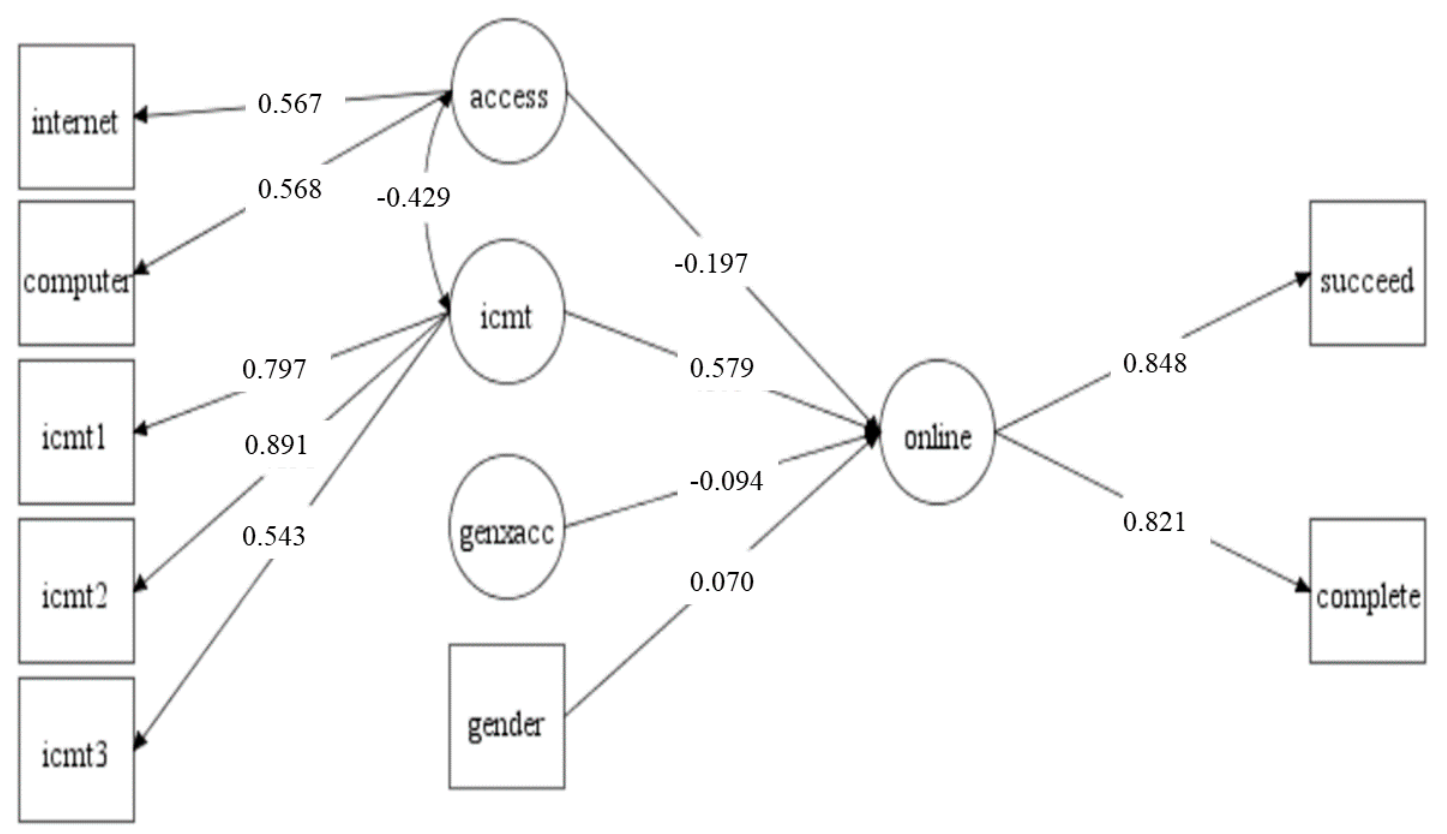

Figure 5. Conceptual diagram of an LMS access model with parameter estimates.

The LMS ICMT model with a loglikelihood difference value of $D=1.734(p>0.05)$ revealed significant gender differences with significant interaction term of gender*ICMT (gendxicmt) with $\beta=0.104$, S.E. $=0.049, p<0.05$ as presented in Figure 6. Thus, hypothesis 4 was supported. Further investigation using the loop plot revealed more pronounced benefits of effective ICMT use among URM female students compared with male students (See Figure 7 for details). 


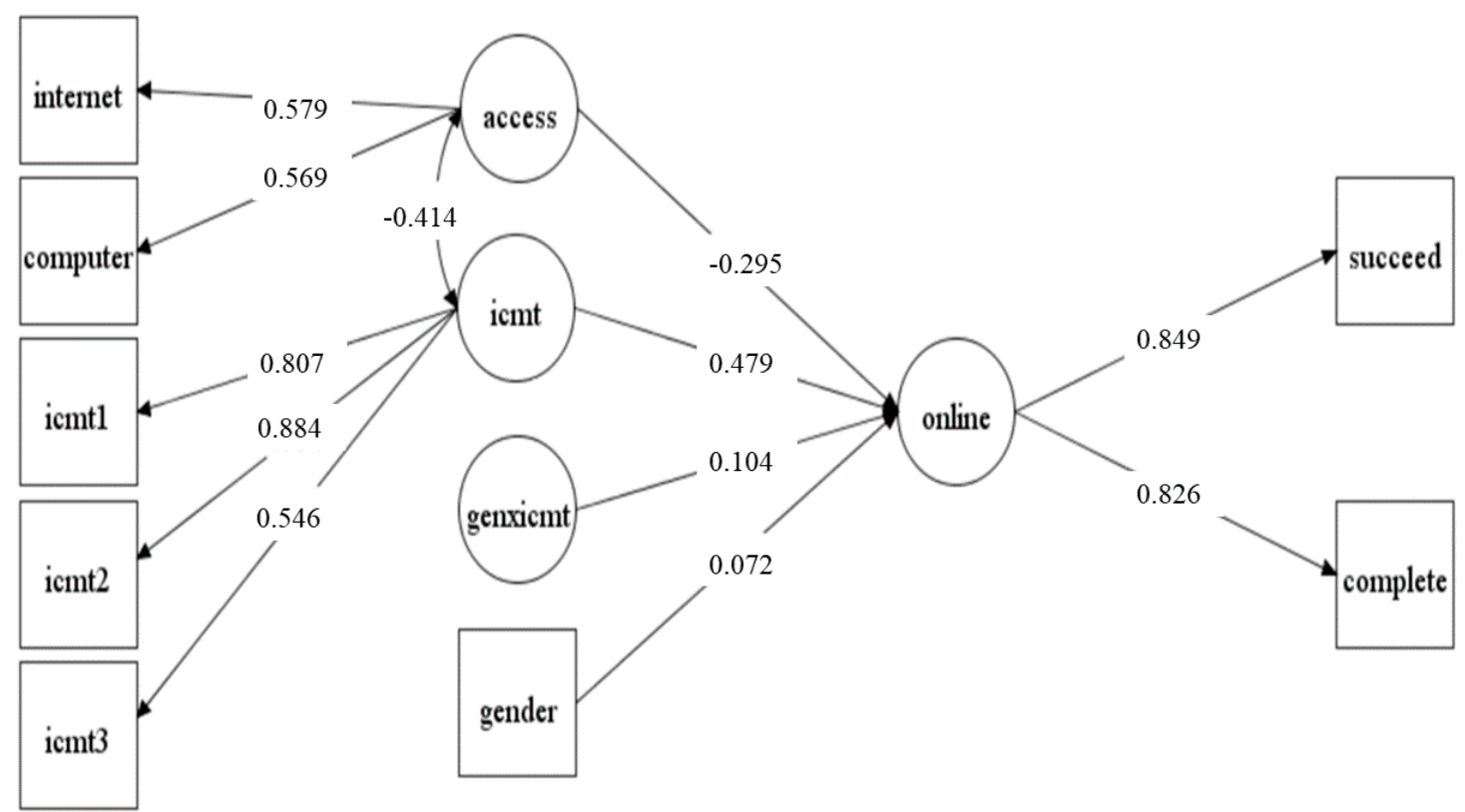

Figure 6. Conceptual diagram of an LMS ICMT model with parameter estimates.

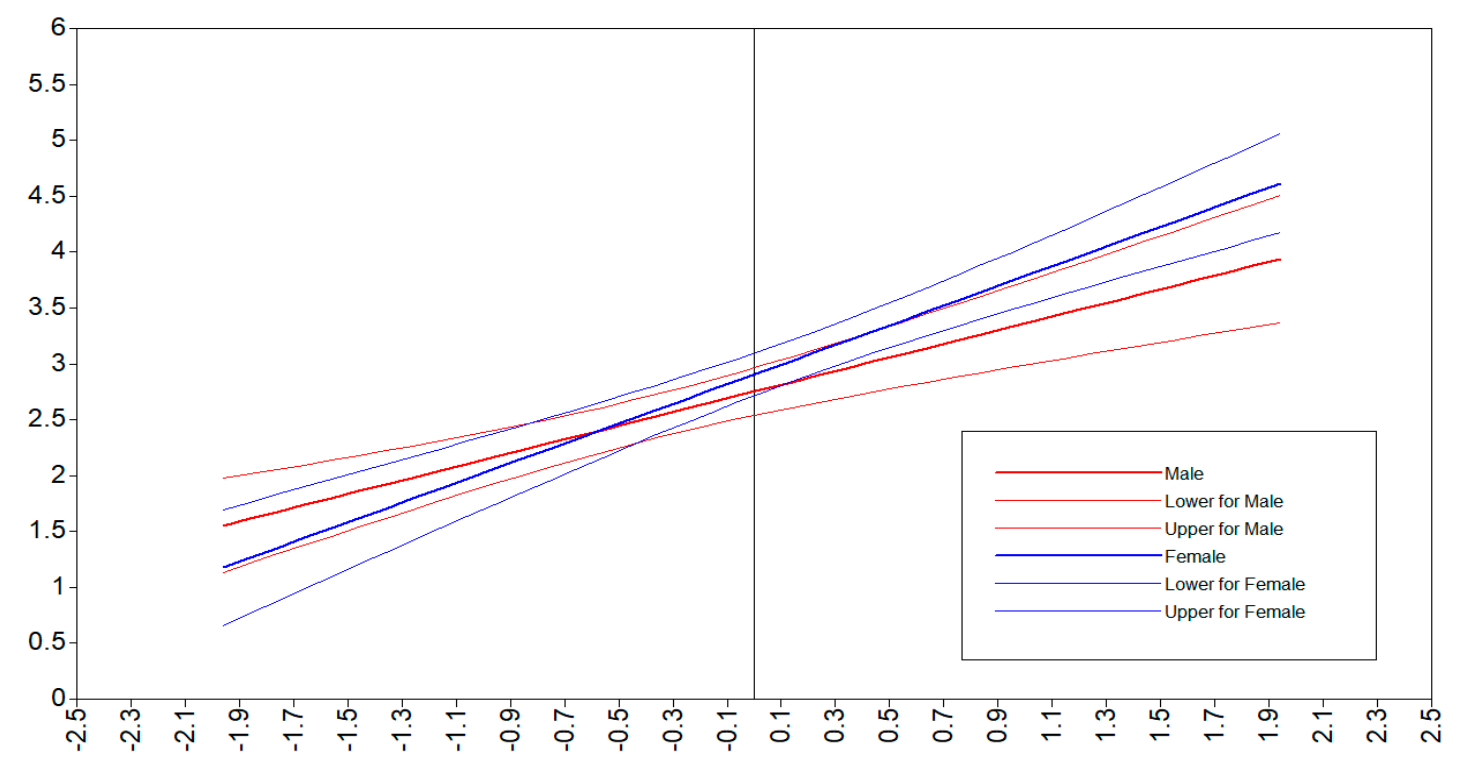

Figure 7. Loop plot for latent interaction effect.

\section{Discussion and Conclusions}

In response to the call for studies on online transitions amid the COVID-19 pandemic [14], we aimed to offer empirical evidence uncovering the role of ICMT access and learning uses in students' perceived online success and digital inclusion in the context of the UN's Sustainable Development Goal 4 [68]. Our finding on ICMT access revealed the need for continued studies on physical ICMT access for both male and female students [69], by supporting the hypothesis 1 on the importance of ICMT access, while not supporting the hypothesis 3 on its differential effect between two gender groups. ICMT access has become a necessity for student learning during the COVID-19 crisis [70], whereas recent studies associated with digital divides have focused more on ICMT usage and skills than on ICMT access [71,72]. Compared to non-URM students, URM students tend to live in communities that suffer more from limited ICMT access, such as poor connections in terms of both data usage and speed [73]. Our finding on the adverse effects of ICMT access on URM students supports further investments in equal home and community access for these students. For example, governments together with 
telecommunication companies can make efforts to expand high-speed Internet network coverage in communities with higher proportions of URM individuals with limited ICMT access, while maintaining places offering public access to computers and the Internet under good hygiene conditions [74].

By supporting hypothesis 2, the study revealed the benefits of ICMT use for online learning for URM students. By adding empirical evidence on ICMT as a potential agent to promote student learning in higher education $[75,76]$, we rendered support for the active use of ICMTs for learning to support the UN's SDG4 of enhancing quality and inclusive education. Specifically, we recommend adopting ICMTs as cognitive tools to promote constructivist-based activities among all students [77,78]. As instructors play a key role in effectively integrating ICMTs as cognitive tools into pedagogical practices, it will be important to further improve instructors' confidence, motivation, and competence with respect to ICMT-integrated learning $[79,80]$. For this, instructors need to be given technical, social, and moral support [81]. Specifically, we recommend that instructors have opportunities to reinforce their ICMT competency and to use and apply ICMTs as pedagogical tools to meet their classes' needs during their ICMT professional development sessions; we recommend also that teachers share their experiences, including their success stories, via ICMT-based instructor communities [82-85].

Given the important role of instructors in students' online learning [86], by having access to the data on nested structures in which students are placed with instructors, future study authors can consider building multilevel SEM analysis to explore the cross-level effects of teachers on students. Future studies can further investigate the psychometric qualities of the instrument on ICMT access, uses, and online success. They can also develop more items related to ICMT access, including additional digital-divide-related ICMTs—such as smartphones and high-speed Internet [13]—as well as ICMTs for learning to measure constructivist-based activities such as problem-based learning $[87,88]$.

As people anticipate unforeseeable futures beyond COVID-19, our study results can contribute to offering effective strategies for schools to prepare for a flexible and adaptable educational system geared towards blended learning using ICMT. Importantly, our study contributes to achieving the UN's SDG4 of ensuring quality and equitable educational opportunities for URM students in the US by promoting digital inclusion, while filling the research gap on ethnic or racial differences in ICMT studies [21]. Considering the critical role of digital inclusion in social inclusion [89], further studies are needed to find ways for applying ICMT to online learning to narrow rather than widen inequalities in the post-COVID-19 era.

Our study did not detect the differential effect of ICMT access between male and female students, with hypothesis 3 not supported. However, by confirming hypothesis 4 , we identified the differential effect of ICMT use, revealing more pronounced benefits among female URM students than male students. Our findings shed insights on the gender responsiveness of online learning for females, who are expected to suffer from lower academic achievement and increased school dropout rates during the (post) COVID-19 era [90]. Furthermore, we call for more studies to investigate gender-responsive and transformative online education, particularly for female students in low-income communities and/or in developing countries who suffer from a more severe digital divide and educational inequalities in the (post) COVID-19 era [91].

Author Contributions: Conceptualization, S.K. and S.R.; methodology, S.K.; formal analysis, S.K.; investigation, S.K., S.R., and Y.C.; resources, S.R.; writing-original draft preparation, S.K., Y.C., and S.P.; writing-review and editing, S.K. and Y.C.; supervision, S.K. and S.R. All authors have read and agreed to the published version of the manuscript.

Funding: This research received no external funding.

Acknowledgments: The authors would like to thank Dr. Carol M Van Zile-Tamsen, Dr. Graham Hammill, Ms. Mary Odden, the Office of Educational Effectiveness, and a task force team for the development of survey instruments and the data collection. *Addition of job title followed by the full name Carol M Van Zile-Tamsen Assistant Vice Provost for Educational Effectiveness (https://www.buffalo.edu/people/cmv3); Graham Lawrence Hammill Vice Provost for Academic Affairs and Dean of the Graduate School (https://www.buffalo.edu/people/ ghammill); Mary J Odden Student Learning Outcomes Specialist (https://www.buffalo.edu/people/maryfish)

Conflicts of Interest: The authors declare no conflict of interest. 


\section{References}

1. UNESCO. 290 Million Students Out of School Due to COVID-19: UNESCO Releases First Global Numbers and Mobilizes Response. Available online: https://en.unesco.org/news/290-million-students-out-school-duecovid-19-unesco-releases-first-global-numbers-and-mobilizes (accessed on 3 August 2020).

2. UNESCO. School Closures Caused by Coronavirus (Covid-19). Available online: https://en.unesco.org/ covid19/educationresponse/ (accessed on 3 August 2020).

3. Do, D.-N.-M.; Hoang, L.-K.; Le, C.-M.; Tran, T. A Human Rights-Based Approach in Implementing Sustainable Development Goal 4 (Quality Education) for Ethnic Minorities in Vietnam. Sustainability 2020, 12, 4179. [CrossRef]

4. Murgatroyd, S. A Cancelled Future: What's Next for Universities and Colleges? Available online: https://www.researchgate.net/profile/Stephen_Murgatrotd/publication/340950824_A_Cancelled_Future_ What $\backslash T 1 \backslash$ textquoterights_Next_for_Universities_and_Colleges/links/5ea70b9892851c1a9073b484/ACancelled-Future-Whats-Next-for-Universities-and-Colleges (accessed on 20 July 2020).

5. Zhang, W.; Wang, Y.; Yang, L.; Wang, C. Suspending classes without stopping learning: China's education emergency management policy in the COVID-19 Outbreak. J. Risk Financ. Manag. 2020, 13, 55. [CrossRef]

6. Erdogdu, F.; Erdogdu, E. The impact of access to ICT, student background and school/home environment on academic success of students in Turkey: An international comparative analysis. Comput. Educ. 2015, 82, 26-49. [CrossRef]

7. Peña-López, I. PISA 2015 Results (Volume I). Excellence and Equity in Education; OECD Publishing: Paris, France, 2016.

8. Wittwer, J.; Senkbeil, M. Is students' computer use at home related to their mathematical performance at school? Comput. Educ. 2008, 50, 1558-1571. [CrossRef]

9. Organisation for Economic Co-operation and Development. OECD Digital Economy Outlook 2015; Organisation for Economic Co-operation and Development: Paris, France, 2015; ISBN 92-64-23244-3.

10. Reisdorf, B.C.; Dutton, W.H.; Triwibowo, W.; Nelson, M.E. The unexplored history of operationalising digital divides: A pilot study. Internet Hist. 2017, 1, 106-118. [CrossRef]

11. The World Bank; World Bank Group. World Development Report 2016: Digital Dividends; World Bank Publications: Washington, DC, USA, 2016; ISBN 1-4648-0671-3.

12. Kim, S. ICT and the UN's Sustainable Development Goal for Education: Using ICT to Boost the Math Performance of Immigrant Youths in the US. Sustainability 2018, 10, 4584. [CrossRef]

13. Chiou, L.; Tucker, C. Social Distancing, Internet Access and Inequality; National Bureau of Economic Research: Cambridge, MA, USA, 2020.

14. Ali, W. Online and Remote Learning in Higher Education Institutes: A Necessity in light of COVID-19 Pandemic. High. Educ. Stud. 2020, 10, 16. [CrossRef]

15. Livingstone, S.; Helsper, E. Gradations in digital inclusion: Children, young people and the digital divide. New Media Soc. 2007, 9, 671-696. [CrossRef]

16. Prensky, M.R. From Digital Natives to Digital Wisdom: Hopeful Essays for 21st Century Learning; Corwin Press: Thousand Oaks, CA, USA, 2012; ISBN 1-4522-8419-9.

17. Liu, D.; Kirschner, P.A.; Karpinski, A.C. A meta-analysis of the relationship of academic performance and Social Network Site use among adolescents and young adults. Comput. Hum. Behav. 2017, 77, 148-157. [CrossRef]

18. Papanastasiou, E.C.; Zembylas, M.; Vrasidas, C. Can computer use hurt science achievement? The USA results from PISA. J. Sci. Educ. Technol. 2003, 12, 325-332. [CrossRef]

19. Ponzo, M. Does the way in which students use computers affect their school performance? J. Econ. Soc. Res. 2011, 13, 1.

20. Heemskerk, I.; Volman, M.; Ten Dam, G.; Admiraal, W. Social scripts in educational technology and inclusiveness in classroom practice. Teach. Teach. Theory Pract. 2011, 17, 35-50. [CrossRef]

21. Volman, M.; Van Eck, E.; Heemskerk, I.; Kuiper, E. New technologies, new differences. Gender and ethnic differences in pupils' use of ICT in primary and secondary education. Comput. Educ. 2005, 45, 35-55. [CrossRef]

22. Kim, S.; Chang, M. Does computer use promote the mathematical proficiency of ELL students? J. Educ. Comput. Res. 2010, 42, 285-305. [CrossRef] 
23. Ritzhaupt, A.D.; Liu, F.; Dawson, K.; Barron, A.E. Differences in Student Information and Communication Technology Literacy Based on Socio-Economic Status, Ethnicity, and Gender: Evidence of a Digital Divide in Florida Schools. J. Res. Technol. Educ. 2013, 45, 291-307. [CrossRef]

24. Tawfik, A.; Reeves, T.; Stich, A. Intended and Unintended Consequences of Educational Technology on Social Inequality. TechTrends Link. Res. Pract. Improv. Learn. 2016, 60, 598-605. [CrossRef]

25. Third, A.; Collin, P.; Walsh, L.; Black, R. Digital Inclusion. In Young People in Digital Society; Springer: Berlin/Heidelberg, Germany, 2019; pp. 129-174.

26. Jenkins, R.; Winthrop, R. 5 Actions to Help Bring the Most Marginalized Girls Back to School after COVID-19. Available online: https://www.brookings.edu/blog/education-plus-development/2020/05/15/5-actions-tohelp-bring-the-most-marginalized-girls-back-to-school-after-covid-19/ (accessed on 21 September 2020).

27. Cai, Z.; Fan, X.; Du, J. Gender and attitudes toward technology use: A meta-analysis. Comput. Educ. 2017, 105, 1-13. [CrossRef]

28. Chyung, S.Y.Y. Age and gender differences in online behavior, self-efficacy, and academic performance. Q. Rev. Distance Educ. 2007, 8, 213.

29. Muthén, L.K.; Muthen, B. Mplus User's Guide: Statistical Analysis with Latent Variables, User's Guide, 8th ed.; Muthén \& Muthén: Los Angeles, CA, USA, 2019; ISBN 0-9829983-2-5.

30. Wang, J.; Wang, X. Structural Equation Modeling: Applications Using Mplus; John Wiley \& Sons: Hoboken, NJ, USA, 2019; ISBN 1-119-42271-X.

31. Attewell, P.; Battle, J. Home computers and school performance. Inform. Soc. 1999, 15, 1-10. [CrossRef]

32. Borgonovi, F.; Organisation for Economic Co-operation and Development; Achiron, M. The ABC of Gender Equality in Education: Aptitude, Behaviour, Confidence; OECD Publishing: Paris, France, 2015; ISBN 92-64-22994-9.

33. Plan International COVID-19: The Impact on Girls. Available online: https://plan-international.org/ publications/covid-19-impact-girls (accessed on 26 September 2020).

34. Siddiq, F.; Scherer, R. Is there a gender gap? A meta-analysis of the gender differences in students' ICT literacy. Educ. Res. Rev. 2019, 27, 205-217. [CrossRef]

35. Hattie, J.A.; Donoghue, G.M. Learning strategies: A synthesis and conceptual model. Npj Sci. Learn. 2016, $1,1-13$.

36. Committee on How People Learn II: The Science and Practice of Learning; Board on Behavioral, Cognitive, and Sensory Sciences; Board on Science Education; Division of Behavioral and Social Sciences and Education; National Academies of Sciences, Engineering, and Medicine. How People Learn II: Learners, Contexts, and Cultures; National Academies Press: Washington, DC, USA, 2018; ISBN 978-0-309-45964-8.

37. Ertmer, P.A.; Ottenbreit-Leftwich, A.T.; Sadik, O.; Sendurur, E.; Sendurur, P. Teacher beliefs and technology integration practices: A critical relationship. Comput. Educ. 2012, 59, 423-435. [CrossRef]

38. Gee, J.P. Games, Learning, and 21st Century Survival Skills. J. Virtual Worlds Res. 2009, 2. [CrossRef]

39. Shute, V.J.; Ventura, M. Measuring and Supporting Learning in Games: Stealth Assessment; The MIT Press: Cambridge, MA, USA, 2013.

40. Vonderwell, S. An examination of asynchronous communication experiences and perspectives of students in an online course: A case study. Internet High. Educ. 2003, 6, 77-90. [CrossRef]

41. Irvin, R.; Macklin, A. Information and communication technology (ICT) literacy: Integration and assessment in higher education. J. Syst. Cybern. Inform. 2007, 5, 50-55.

42. Hughes, M.; Daykin, N. Towards Constructivism: Investigating Students' Perceptions and Learning as a Result of Using an Online Environment. Innov. Educ. Teach. Int. 2002, 39, 217-224. [CrossRef]

43. Albugami, S.; Ahmed, V. Success factors for ICT implementation in Saudi secondary schools: From the perspective of ICT directors, head teachers, teachers and students. Int. J. Educ. Dev. Using ICT 2015, 11, 36-54.

44. Sheard, J.; Carbone, A.; Hurst, A.J. Student Engagement in First Year of an ICT Degree: Staff and Student Perceptions. Comput. Sci. Educ. 2010, 20,1-16.

45. Song, L.; Singleton, E.S.; Hill, J.R.; Koh, M.H. Improving online learning: Student perceptions of useful and challenging characteristics. Internet High. Educ. 2004, 7, 59-70. [CrossRef]

46. Alexander, B.; Ashford-Rowe, K.; Barajas-Murph, N.; Dobbin, G.; Knott, J.; McCormack, M.; Pomerantz, J.; Seilhamer, R.; Weber, N. Horizon Report 2019 Higher Education Edition; EDUCAUSE: Louisville, CO, USA, 2019.

47. Statista Digital Users Worldwide 2020 | Statista. Available online: https://www.statista.com/statistics/617136/ digital-population-worldwide/ (accessed on 3 August 2020). 
48. Al-Oteawi, S.M. The Perceptions of Administrators and Teachers in Utilizing Information Technology in Instruction, Administrative Work, Technology Planning and Staff Development in Saudi Arabia; Ohio University: Athens, OH, USA, 2002; ISBN 0-493-77951-5.

49. Albirini, A. Cultural perceptions: The missing element in the implementation of ICT in developing countries. Int. J. Educ. Dev. Using ICT 2006, 2, 49-65.

50. Warschauer, M.; Knobel, M.; Stone, L. Technology and Equity in Schooling: Deconstructing the Digital Divide. Educ. Policy 2004, 18, 562-588. [CrossRef]

51. Palma-Rivas, N. Using Technology to Facilitate Learning for Minority Students. New Dir. Community Coll. 2000, 2000, 73-83. [CrossRef]

52. Brown, M.G.; Wohn, D.Y.; Ellison, N. Without a map: College access and the online practices of youth from low-income communities. Comput. Educ. 2016, 92-93, 104-116. [CrossRef]

53. Du, J.; Ge, X.; Xu, J. Online collaborative learning activities: The perspectives of African American female students. Comput. Educ. 2015, 82, 152-161. [CrossRef]

54. Smith, D.R.; Ayers, D.F. Culturally responsive pedagogy and online learning: Implications for the globalized community college. Commun. Coll. J. Res. Pract. 2006, 30, 401-415. [CrossRef]

55. Little, R.J. A test of missing completely at random for multivariate data with missing values. J. Am. Stat. Assoc. 1988, 83, 1198-1202. [CrossRef]

56. Allison, P.D. Missing Data; Sage publications: Thousand Oaks, CA, USA, 2001; Volume 136, ISBN 1-4522-0790-9.

57. Walters, G.D.; Espelage, D.L. Mediating the bullying victimization-delinquency relationship with anger and cognitive impulsivity: A test of general strain and criminal lifestyle theories. J. Crim. Justice 2017, 53, 66-73. [CrossRef]

58. Enders, C.K. The impact of nonnormality on full information maximum-likelihood estimation for structural equation models with missing data. Psychol. Methods 2001, 6, 352. [CrossRef]

59. Lai, K. Estimating standardized SEM parameters given nonnormal data and incorrect model: Methods and comparison. Struct. Equ. Model. Multidiscip. J. 2018, 25, 600-620. [CrossRef]

60. Dong, Y.; Peng, C.-Y.J. Principled missing data methods for researchers. SpringerPlus 2013, 2, 222. [CrossRef]

61. Kline, R.B. Principles and Practice of Structural Equation Modeling; Guilford publications: New York, NY, USA, 2015; ISBN 1-4625-2335-8.

62. McDonald, R.P. The theoretical foundations of principal factor analysis, canonical factor analysis, and alpha factor analysis. Br. J. Math. Stat. Psychol. 1970, 23, 1-21. [CrossRef]

63. Padilla, M.A.; Divers, J. A comparison of composite reliability estimators: Coefficient omega confidence intervals in the current literature. Educ. Psychol. Meas. 2016, 76, 436-453. [CrossRef]

64. Dunn, T.J.; Baguley, T.; Brunsden, V. From alpha to omega: A practical solution to the pervasive problem of internal consistency estimation. Br. J. Psychol. 2014, 105, 399-412. [CrossRef]

65. Schumacker, R.E.; Lomax, R.G. A Beginner's Guide to Structural Equation Modeling; Psychology Press: Mahwah, NJ, USA, 2004; ISBN 1-135-64192-7.

66. Maslowsky, J.; Jager, J.; Hemken, D. Estimating and interpreting latent variable interactions: A tutorial for applying the latent moderated structural equations method. Int. J. Behav. Dev. 2015, 39, 87-96. [CrossRef] [PubMed]

67. Gerhard, C.; Klein, A.G.; Schermelleh-Engel, K.; Moosbrugger, H.; Gäde, J.; Brandt, H. On the performance of likelihood-based difference tests in nonlinear structural equation models. Struct. Equ. Model. Multidiscip. J. 2015, 22, 276-287. [CrossRef]

68. United Nations Transforming Our World: The 2030 Agenda for Sustainable Development: Goal 4 । Department of Economic and Social Affairs. Available online: https://sdgs.un.org/goals/goal4 (accessed on 3 August 2020).

69. Freeman, J.; Park, S.; Middleton, C. Technological literacy and interrupted internet access. Inf. Commun. Soc. 2019, 1-18. [CrossRef]

70. Van Lancker, W.; Parolin, Z. COVID-19, school closures, and child poverty: A social crisis in the making. Lancet Public Health 2020, 5, e243-e244. [PubMed]

71. Van Deursen, A.J.; Van Dijk, J.A. The digital divide shifts to differences in usage. New Media Soc. 2014, 16, 507-526. [CrossRef]

72. $\quad$ van Dijk, J. The Digital Divide; John Wiley \& Sons: Hoboken, NJ, USA, 2020; ISBN 1-5095-3446-6. 
73. Rappoport, P.; Kridel, D.J.; Taylor, L.D.; Alleman, J.; Duffy-Deno, K.T. Residential demand for access to the Internet. Emerg. Telecommun. Netw. Int. Handb. Telecommun. Econ. 2003, 1, 55-72.

74. Beaunoyer, E.; Dupéré, S.; Guitton, M.J. COVID-19 and digital inequalities: Reciprocal impacts and mitigation strategies. Comput. Hum. Behav. 2020, 111, 106424.

75. Jaffer, S.; Ng'ambi, D.; Czerniewicz, L. The role of ICTs in higher education in South Africa: One strategy for addressing teaching and learning challenges. Int. J. Educ. Dev. Using ICT 2007, 3, 131-142.

76. Rosen, L.D. Rewired: Understanding the IGeneration and the Way They Learn; St. Martin's Press: New York, NY, USA, 2010; ISBN 0-230-10608-0.

77. Jonassen, D.; Jonassen, D.H.; Land, S. (Eds.) Theoretical Foundations of Learning Environments; Routledge: Abingdon-on-Thames, UK, 1999; ISBN 0-8058-3216-5.

78. Jonassen, D.H. Toward a design theory of problem solving. Educ. Technol. Res. Dev. 2000, 48, 63-85. [CrossRef]

79. Coll, C.; Mauri, T.; Onrubia, J. Towards modeling of the teaching-learning mediated by ICT. Educ. Technol. 2009, 5, 145-161.

80. Twidle, J.; Sorensen, P.; Childs, A.; Godwin, J.; Dussart, M. Issues, challenges and needs of student science teachers in using the Internet as a tool for teaching. Technol. Pedagogy Educ. 2006, 15, 207-221. [CrossRef]

81. World Bank. Remote Learning and COVID-19; World Bank: Washington, DC, USA, 2020.

82. Aczel, J.C.; Peake, S.R.; Hardy, P. Designing capacity-building in e-learning expertise: Challenges and strategies. Comput. Educ. 2008, 50, 499-510. [CrossRef]

83. Ertmer, P.A.; Ottenbreit-Leftwich, A.T. Teacher technology change: How knowledge, confidence, beliefs, and culture intersect. J. Res. Technol. Educ. 2010, 42, 255-284. [CrossRef]

84. Jung, I. ICT-pedagogy integration in teacher training: Application cases worldwide. J. Educ. Technol. Soc. 2005, 8, 94-101.

85. Kay, R.H. Evaluating strategies used to incorporate technology into preservice education: A review of the literature. J. Res. Technol. Educ. 2006, 38, 383-408. [CrossRef]

86. Fu, J. Complexity of ICT in education: A critical literature review and its implications. Int. J. Educ. Dev. Using ICT 2013, 9, 112-125.

87. Evensen, D.H.; Hmelo-Silver, C.E. Problem-Based Learning: A Research Perspective on Learning Interactions; Routledge: Abingdon-on-Thames, UK, 2000; ISBN 1-135-68455-3.

88. Gijbels, D.; Dochy, F.; Van den Bossche, P.; Segers, M. Effects of problem-based learning: A meta-analysis from the angle of assessment. Rev. Educ. Res. 2005, 75, 27-61. [CrossRef]

89. Reisdorf, B.; Rhinesmith, C. Digital Inclusion as a Core Component of Social Inclusion. Soc. Incl. 2020, 8, 132-137. [CrossRef]

90. Giannini, S.; Albrectsen, A. COVID-19 School Closures around the World Will Hit Girls Hardest. Available online: https://planinternational.org/blog/2020/03/covid-19-school-closures-hit-girls-hardest (accessed on 21 September 2020).

91. Malala Fund Girls' Education and COVID-19. Available online: https://downloads. ctfassets.net/0oan5gk9rgbh/6TMYLYAcUpjhQpXLDgmdIa/dd1c2ad08886723cbad85283d479de09/ GirlsEducationandCOVID19_MalalaFund_04022020.pdf (accessed on 20 September 2020).

Publisher's Note: MDPI stays neutral with regard to jurisdictional claims in published maps and institutional affiliations.

(C) 2020 by the authors. Licensee MDPI, Basel, Switzerland. This article is an open access article distributed under the terms and conditions of the Creative Commons Attribution (CC BY) license (http://creativecommons.org/licenses/by/4.0/). 